Original Research Paper

\title{
Species Assemblages and Distribution of Dinoflagellate Cysts from three Estuaries Sediment's of Makassar Strait, Eastern Indonesia
}

\author{
1*Nita Rukminasari and ${ }^{2}$ Akbar Tahir \\ ${ }^{1}$ Department of Fisheries, Faculty of Marine Science and Fisheries, Universitas Hasanuddin, Makassar, Indonesia \\ ${ }^{2}$ Department of Marine Science, Faculty of Marine Science and Fisheries, Universitas Hasanuddin, Makassar, Indonesia
}

\author{
Article history \\ Received: 21-09-2020 \\ Revised: 09-11-2020 \\ Accepted: 23-11-2020 \\ Corresponding Author: \\ Nita Rukminasari \\ Department of Fisheries, \\ Faculty of Marine Science and \\ Fisheries, Universitas \\ Hasanuddin, Makassar, \\ Indonesia \\ Email: nita.r@unhas.ac.id
}

\begin{abstract}
Makassar Strait encompasses high fisheries resources and high biodiversity and primary productivity. Algae blooms often occur in these areas, but there is a lack of studies that have been carried out on HABs in these locations specifically determining the collection and abundance of dinocyst. The study aimed to determine species assemblages of dinoflagellate cysts from three estuaries of Makassar Strait. Sampling was conducted at three locations, i.e., Jeneberang, Maros and Pangkep Estuaries during July 2020. Each location of sampling consisted of 4 stations and 3 substations as a sampling replication. Variables that were measured in this study were dinoflagellate cysts abundance species assemblages and distribution. Results showed that there was no clear group of dinoflagellate cysts assemblages between locations, however dinoflagellate cyst assemblages from Jeneberang Estuary was significantly grouped. We recorded 48 dinoflagellate cysts species that belonged to 5 families, namely Goniodomaceae, Gonyaulacaceae, Gymnodiniacea, Peridiniaceae and Protoperidiniaceae. The dominant species of dinoflagellate cysts from Jeneberang Estuary was Scrippsiella crystallina, meanwhile the dominant dinoflagellate cyst from Maros and Pangkep Estuary was Gonyaulax verior and Pentapharsodinium tyrrhenicum, respectively. Scrippsiella trifida was a dinoflagellate cysts species was contributed to the dissimilarity of cyst assemblages between locations. We also found potential five toxic dinoflagellate cyst species. In conclusion, the dinoflagellate cysts species composition, diversity, species richness and cyst abundance was not significant difference between stations of all locations. The abundance of dinoflagellate cysts was significantly correlated by sediment grain size. All sampling sites has a potentially occurred of HABs due to the five potential cysts toxic and harmful species discovered.
\end{abstract}

Keywords: Dinoflagellate Cysts, Species Assemblages and Dsistribution, Jeneberang, Maros and Pangkep Estuary and Makassar Strait

\section{Introduction}

In coastal and estuarine waters, phytoplankton is dominated by dinoflagellates and they are the most diverse organisms in the aquatic ecosystem. They could be as autotrophs, which produce their food and heterotrophs that utilize organic compounds for growth and reproduction (Tiselius and Kuylenstierna, 1996). Many dinoflagellates have two-phase of their life cycle, namely an asexual vegetative phase, which reproduction through the fusion of two cells and a sexual phase, which involving gamete fusion process (Mohamed and Al-Shehri, 2011). Sexual reproduction produces a motile cell, the zygote, which can be back to the vegetative stage or become a hypnozoite, or resting cyst. This vegetative state could be able as a plankton which swim in the water column and as a benthic that leave in the bottom sediments (Figueroa et al., 2007). Cysts can live in sediments for more than 5 years. When the favorable condition (mainly temperature) occurred, cysts that leave in the sediment as a feed bank could be creating plankton blooms in the water column (Lewis et al., 1999). Resting stage of many dinoflagellate species are very resistant to the changing of physical, chemical and biological factors (D'Silva et al., 2013). 
One of an important role in the ecology of Harmful Algal Blooms (HABs) in particular for the dinoflagellate group was dinoflagellate resting cysts (Figueroa et al., 2007; Hallegraeff $e t$ al., 2004) and they are a fundamental attribute for dinoflagellate life cycles (Elbrächter, 2003). Hallegraeff et al., 2004; Nehring, 1993a) recorded that about 100 marine and freshwater dinoflagellates out of 2000 extant species have been shown to produce resting cysts. More than 20 of these dinoflagellates' cysts are known could cause HABs (Nehring, 1993b).

Temperature, salinity, nutrients and pollution are an environmental factors that influence the population of dinoflagellates and can also form cysts under unfavorable conditions. Dinoflagellate cysts in the sediment provide information on the dinoflagellates present in the water column (Anderson and Wall, 1978; Dale, 1976). The trophic form of dinoflagellate cyst (phototrophic and heterotrophic) is important information due to they have a different environmental and nutrition requirements (Harland et al., 2004).

Several biological and environmental factors: Primary production and physicochemical conditions (e.g., sea-surface temperature and salinity) could control a cysts distribution dynamics (Candel et al., 2012), including physical characteristics of sediment (Anderson et al., 2005; Anglès et al., 2010; Horner et al., 2011). Triki et al. (2017) found that fine sediment fractions are affected cyst abundances.

The information relates to the characterization of the distributional patterns of harmful species in both water column and sediments and identification of the microalgal community associated with these species are important (Glibert and Pitcher, 2001). Dinoflagellate cyst assemblages, distribution and environmental factors influencing their life are important to be studied for better utilization of dinoflagellate cysts as an indicator of environmental fluctuations (Eynaud et al., 2004; Holzwarth et al., 2007).

Makassar Strait has a high fisheries resources and also a high biodiversity and primary productivity. Increasing anthropogenic disturbance to those areas in particular increasing organic pollution from agricultural areas caused increasing nitrogen and phosphorous concentration. This condition caused eutrophication of waters. Eutrophication is one factor that could trigger the occurrence of algal bloom. Algal bloom in this area could negatively affect ecosystem health and large scale of fish death. The algal bloom often occurs in those areas, however, there is a lack of study that has been conducted about the distribution of dinoflagellate cysts in these areas. Based on this reason, it is important to conduct a study for determining the abundance, assemblages and distribution of dinoflagellate cyst at three estuarine of Makassar Strait, so that we could detect and map the occurrence of HABs at those areas.

\section{Materials and Methods}

\section{Study Sites}

In this study, we researched Makassar Strait, with several sites, namely Jeneberang Estuary (Gowa Regency), Maros Estuary (Maros Regency) and Pangkep Estuary (Pangkep Regency) (Fig. 1). Those areas were selected due to the presence of big rivers nearby respectively and extensive area of estuarine and also are very vulnerable to anthropogenic disturbance and with a high level of organic pollution and as a result, those area has a high potential for HABs occurrence.

\section{Sediment Sampling}

Sediment samples were collected from 3 locations in Makassar Strait (Fig. 1) in July 2020. Each location consisted of 4 stations and 3 substations as a replicate of sampling. The sediment sample was collected using Wilder hand corer and was taken $5 \mathrm{~cm}$ of surface bottom sediment. Before samples was processed, samples were stored in the dark at $10^{\circ} \mathrm{C}$.

\section{Cyst Analysis}

\section{Sediment Processing}

Surface samples sediment were obtained by removing the top $1 \mathrm{~cm}$ of sediment from each core. For the profiles, sample sediment was weight. Weighing sediment of each section was suspended in Filtered Seawater (FSW) and sonicated using Granbo 008 digital ultrasonic cleaner for $15 \mathrm{~min}$. The sonicated material was filtered through three levels of mesh-size sieved (250, 100 and $20 \mu \mathrm{m}$ mesh-size) and collected on the $20 \mu \mathrm{m}$ mesh size. The fine particle that passed $20 \mu \mathrm{m}$ mesh size was washed with FSW and transferred into a $10 \mathrm{~mL}$ vial bottle.

\section{Cyst Counts and Identification}

For dinoflagellate cyst analysis, the top fraction (0-2 $\mathrm{cm})$ which represents recent sediment sieved using the method of (Matsuoka and Fukuyo, 2000). Each sediment sample was sonicated for $15 \mathrm{~min}$ and sieved through 250 , 100 and $20 \mu \mathrm{m}$ mesh-sizes. Fine particle that has been passed on the $20 \mu \mathrm{m}$ mesh was transferred to a petri dish and let sedimented for $15 \mathrm{~min}$, upper layer of solution then transferred into $10 \mathrm{~mL}$ vial and observed under a light microscope with the magnification of 100-400 times. Dinoflagellate cysts were identified based on published descriptions (Alkawri, 2016; Aydin et al., 2011; Bravo et al., 2006; Godhe et al., 2000; Joyce et al., 2005; Kim et al., 2012; Mohamed and Al-Shehri, 2011; Narale and Anil, 2017; Nehring, 1997; Pospelova et al., 2004; Shin et al., 2011; Uddandam et al., 2017). The unit of cyst abundance was the number of cysts $\mathrm{g}^{-1}$ dry weight sediment. To measure the water content of each sample, a subsample 
Nita Rukminasari and Akbar Tahir / OnLine Journal of Biological Sciences 2021, 21 (2): 232.244 DOI: 10.3844/ojbsci.2021.232.244

was weighed wet and then dried in a $70^{\circ} \mathrm{C}$ oven for 24 $\mathrm{h}$ to obtain the dry weight. The water content and dinoflagellate cyst abundance were calculated following the formula: Cysts/g = N/W(1-R) (Matsuoka and Fukuyo, 2000). Where: $\mathrm{N}=$ Observed cyst number; $W=$ wet sediment weight and $\mathrm{R}=$ water content rate.

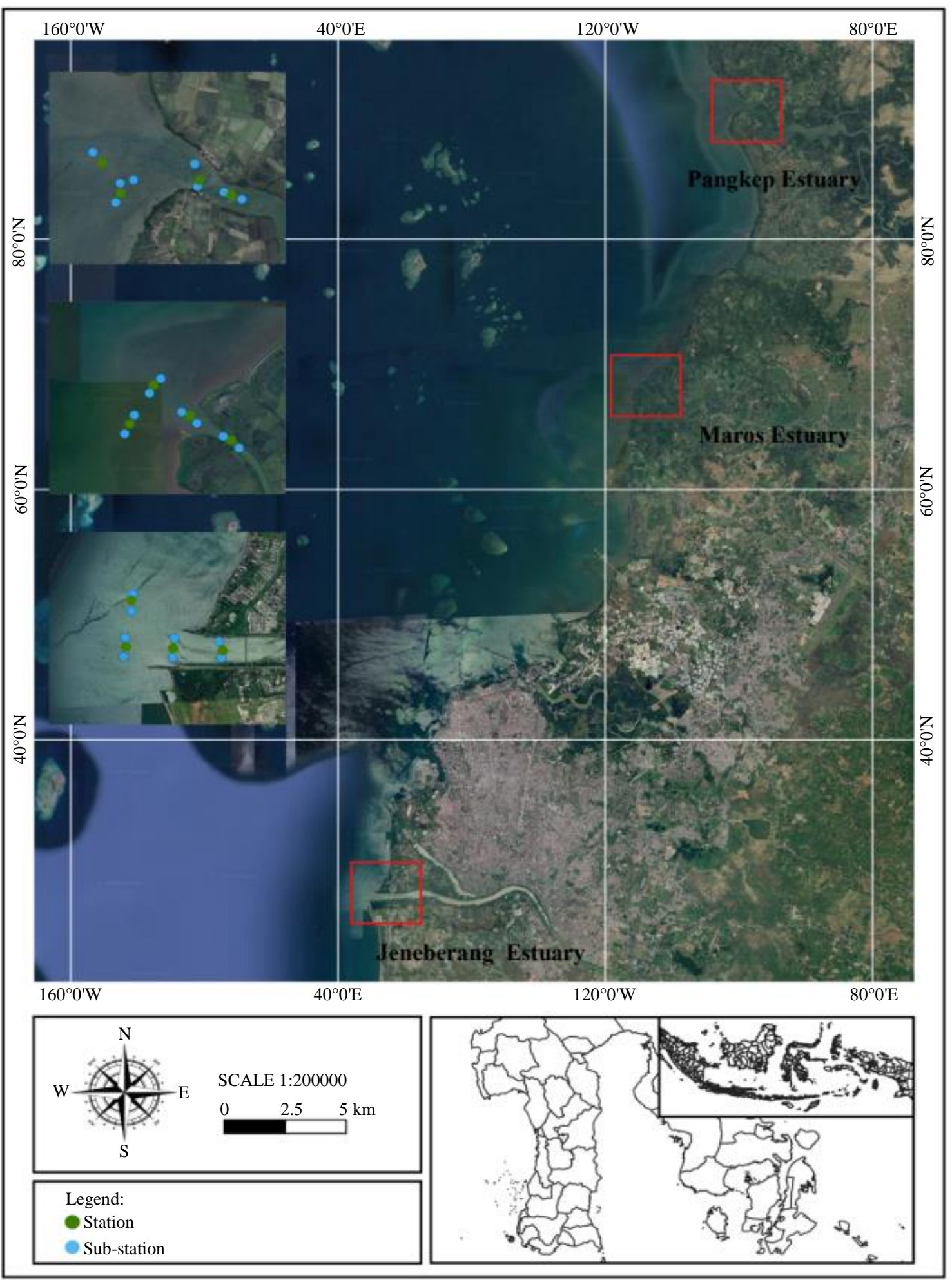

Fig. 1: Study sites map 


\section{Water and Sediment Parameters}

Sediment samples were also collected using Eijkman Drag. Parameters from sediment that were analysis including sediment texture, total carbon, inorganic carbon and total nitrogen. Standard wet sieving was used for measuring sediment texture (percentage of sand, silt and clay content). The Total Carbon (TC) was analyzed using Loss of weight On Ignition (LOI \%) according to (Meng et al., 2014). Total Nitrogen (TN) contents was analyzed using Kjeldahl method with detail analysis according to (Bremner, 1996). Total Inorganic Carbon (TIC) content was estimated with modified pressurecalcimeter method (Sherrod et al., 2002).

\section{Data Analysis}

PRIMER - version 5 (PRIMER-E Ltd. Plymouth, UK) was used for analysis Shannon-Wiener's diversity index (H'), Margalef's species richness (d) and Pielou's evenness (J')). nMDS, ANOSIM and SIMPER as a PRIMER routine were also applied. We used log $(x+1)$ transformation of the abundant taxa. For measuring similarity Bray-Curtis coefficient was used. To examine a spatial variation of dinoflagellate cyst abundance, Shannon-Wiener's diversity index ( $\left.H^{\prime}\right)$, Margalef's species richness $(d)$ and Pielou's evenness $\left(J^{\prime}\right)$, two-way ANOVA was performed using GraphPad 7 software program

\section{Results}

\section{Dinoflagellate Cyst Taxa and Abundance}

Overall, 48 dinoflagellate cyst species belonging to 25 genera were recorded in the sediment of three estuaries of Makassar Strait (Jeneberang Estuary, Maros Estuary and Pangkep Estuaries). The list of dinoflagellate cyst species found in surface sediment from three estuaries of Makassar Strait has been given in Supplement 1. The highest number of identified taxa per single sample was found in Maros Estuary station IV substation 2, 17 taxa, followed by 14 taxa in Pangkep Estuary station I substation 3, Maros Estuary station 3 substations 1 and Jeneberang Estuary station II substation 3 and the lowest, only 2 taxa in Maros Estuary station III substation 2. Total cyst abundance ranged from 35 cysts $\mathrm{g}^{-1} \mathrm{DW}$ sediment (in Station 4 substation 3 of Pangkep Estuary) to 1135 cysts $\mathrm{g}^{-1}$ DW sediment (in station 1 substation 2 of Pangkep Estuary) (Fig. 2a) and did not show a significant spatial variation (two-way ANOVA). The number of species ranged from 2 to 17 within the investigated samples. Shannon diversity $\left(\mathrm{H}^{\prime}\right)$ ranges from 0.2959 to 1.159 (Fig. $2 \mathrm{~d})$. The highest species diversity was recorded in the Maros Estuary station IV substation 2. The lowest species diversity was found in Maros Estuary station III substation 2. Species richness ranged from 0.3102 (Jeneberang Estuary station I substation 3) to 2.9376 (Maros Estuary station IV substation 3) (Fig. 2b).

The highest and the lowest Pileou's evenness index (J') were found at Maros Estuary station III substation 2 and Pangkep Estuary station I substation 2 accounting for 0.9829 and 0.5034 , respectively (Fig. 2c). However, there was no significant difference in the univariate measure of dinoflagellate cyst (cyst abundance, species diversity, richness and evenness) between locations and station samplings (Table 1).

\section{Assemblages and Community Structure of Dinoflagellate Cyst}

We were recorded of dinoflagellate cysts from all sediment samples (Table 1) belong to 5 families, namely Goniodomaceae, Gonyaulacaceae, Gymnodiniacea, Peridiniaceae and Protoperidiniaceae. Goniodomaceae consisted of five species: Alexadrium cf. tamarense, Alexandrium catenella, Alexandrium cf. minutum, Alexandrium cf.tamiyavanachi, Alexandrium pseudogonyualax. This family contributed $8 \%$ of the total species found (Fig. 3). The highest percentage of total species belonged to the family of Peridiniaceae, which consisted of 16 species (Fig. 3), namely: Bicarinellum bicarinelloides, Brigatedinium asymmetricum, Dubridinium spp., Dubridinium spp., Potter, Echidinium granulatum, Lejeunecysta oliva, Operculodinium centrocarpum, Scrippsiella cf. lachrymose, Scrippsiella cf.rotunda, Scrippsiella crystallina, Scrippsiella trifida, Scrippsiella trochoides, Selenopemprix nephroides, Sxrystallin sp, Votadiniium spinosum, Zygabikodinium lenticulatum. Gonyaulacaceae and Gymnodiniaceae were contributed the same percentage from the total dinoflagellate cyst species, accounting for $14 \%$, which was contributing 7 species of dinoflagellate cysts (Fig. 3).

When the log mean abundance of dinoflagellate cyst in each location was subjected to ordination, the plot depicting the relationships between the assemblages of dinoflagellate cysts in the different station showed that the samples were initially widespread on the plot for all locations, with the point for Maros Estuary and Pangkep Estuary overlying each other (Fig. 4). The ordination plots for the dinoflagellate cyst communities at Jeneberang Estuary showed that the points for each station formed a relatively tight group that were discrete from each other (Fig. 4a). Furthermore, in three other locations, the points of the stations were overlapped each other (Fig. 4b and 4c). ANOSIM results showed that there was a significant difference in dinoflagellate cyst assemblages between stations for all locations (Supplement 2). 
SIMPER result showed that each station for each location was dominated by different species from a different family. In general, family Peridiniaceae, Protoperidiniaceae and Ganyualacaceae was the dominant family at all stations for all locations (Supplement 2). Interestingly, Pentapharsodinium tyrrhenicum was dinoflagellate cyst which was dominant at station 2 for all locations, furthermore for Jeneberang Estuary and Pangkep Estuary in station III had the same species which was dominated, that was Scrippsiella crystallina.

The percentage of dissimilarity between stations for all locations ranged from 41.62 to 78.85 . The highest dissimilarity percentage was found at the pair of the station I vs station II for Jeneberang Estuary with the taxa that the most contributed for dissimilarity was Scrippsiella crystallina. Furthermore, the pair of the station I vs station II for Maros Estuary had the lowest percentage of dissimilarity with the taxa most contributed for dissimilarity was Scrippsiella trifida.

\section{Water and Sedimentary Parameters at three Estuaries of Northern Makassar Strait}

A higher temperature $\left(32.08^{\circ} \mathrm{C}\right)$ was recorded at station 1 of Jeneberang Estuary and lower temperature $\left(30.40^{\circ} \mathrm{C}\right.$ ) was found at Maros Estuary station 3 (Table 2). The salinity value ranged from 25.41 PSU (Maros Estuary station I) to 32.95 PSU (Jeneberang Estuary station IV). The highest DO was recorded at Maros Estuary station IV accounting for $6.18 \mathrm{mgL}^{-1}$, Jeneberang Estuary station III had the lowest DO, which was $4.31 \mathrm{mgL}^{-1}$. $\mathrm{pH}$ was varied between station for each location, the ranged of $\mathrm{pH}$ value from 6.74 to 7.58. Locations of dinoflagellate cyst sampling in the study were mostly sandy sediment texture, where there were only two stations which have a silt sediment texture, namely Jeneberang Estuary station II and Pangkep Estuary station I. The ranged of TOC was from $0.09 \%$ (Jeneberang Estuary station IV) to $0.91 \%$ (Maros Estuary station III), meanwhile, we recorded TIC varied between stations and locations. The highest TIC was found at Jeneberang Estuary station IV accounting for $26.72 \%$ and Maros Estuary station I had the lowest TIC, which was $0.08 \%$. We also found that undetected TIC for Maros Estuary station III and IV. TN content was similar value from all stations and locations, ranged from 0.01 to $0.05 \%$. Furthermore, the highest and the lowest Corg: $\mathrm{N}$ ratio were found at Jeneberang Estuary station III and I, accounting for 32.77 and 6.64, respectively.
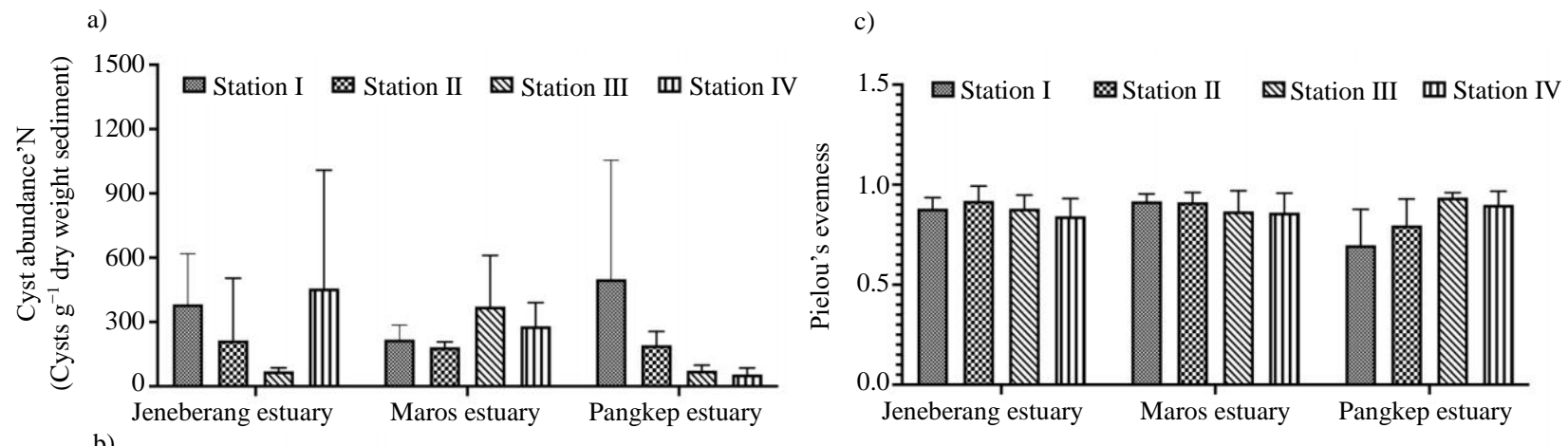
b)

d)
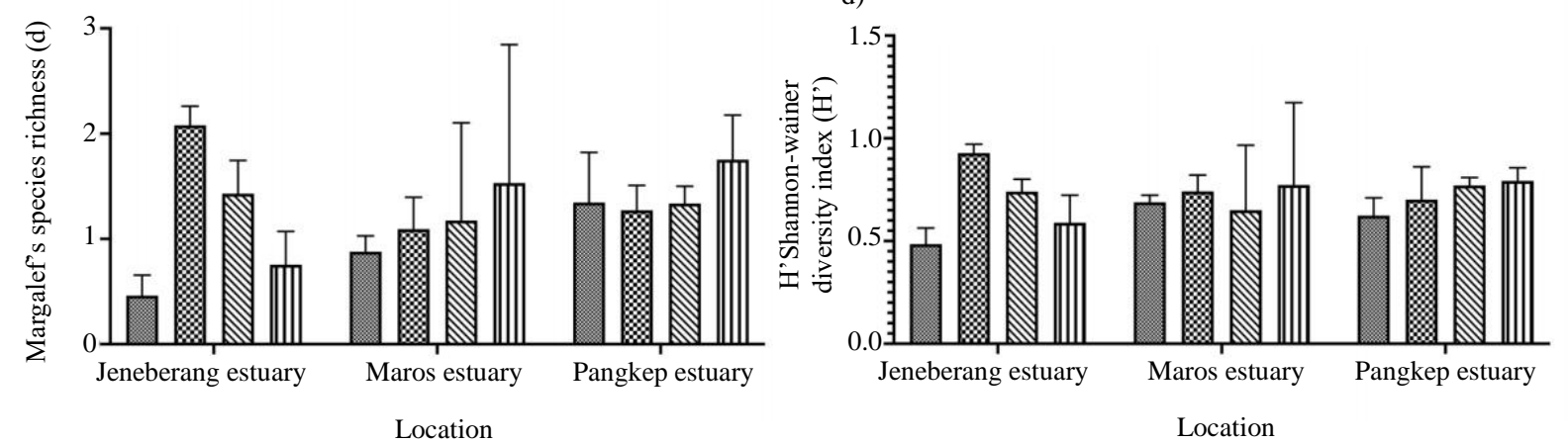

Fig. 2: Spatial variation in (a) dinoflagellate cyst abundance: N, (b) Margalef's species richness: d, (c) Pielou's evenness: J' and (d) Shannon- Wiener's diversity index: H' at three estuaries of MAakassar Strait 


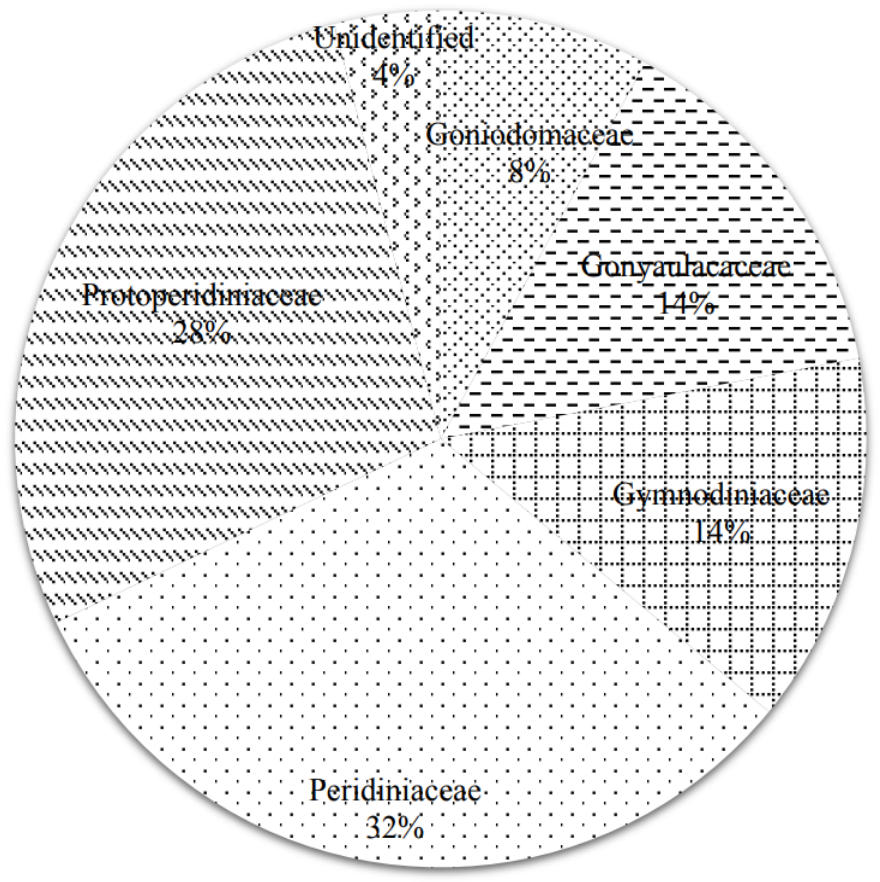

Fig. 3: Percentage composition cysts group: Goniodomaceae, Gonyaulacaceae, Gymnodiniaceae, Peridiniacea and Protoperidiniaceae in three estuaries of Makassar Strait

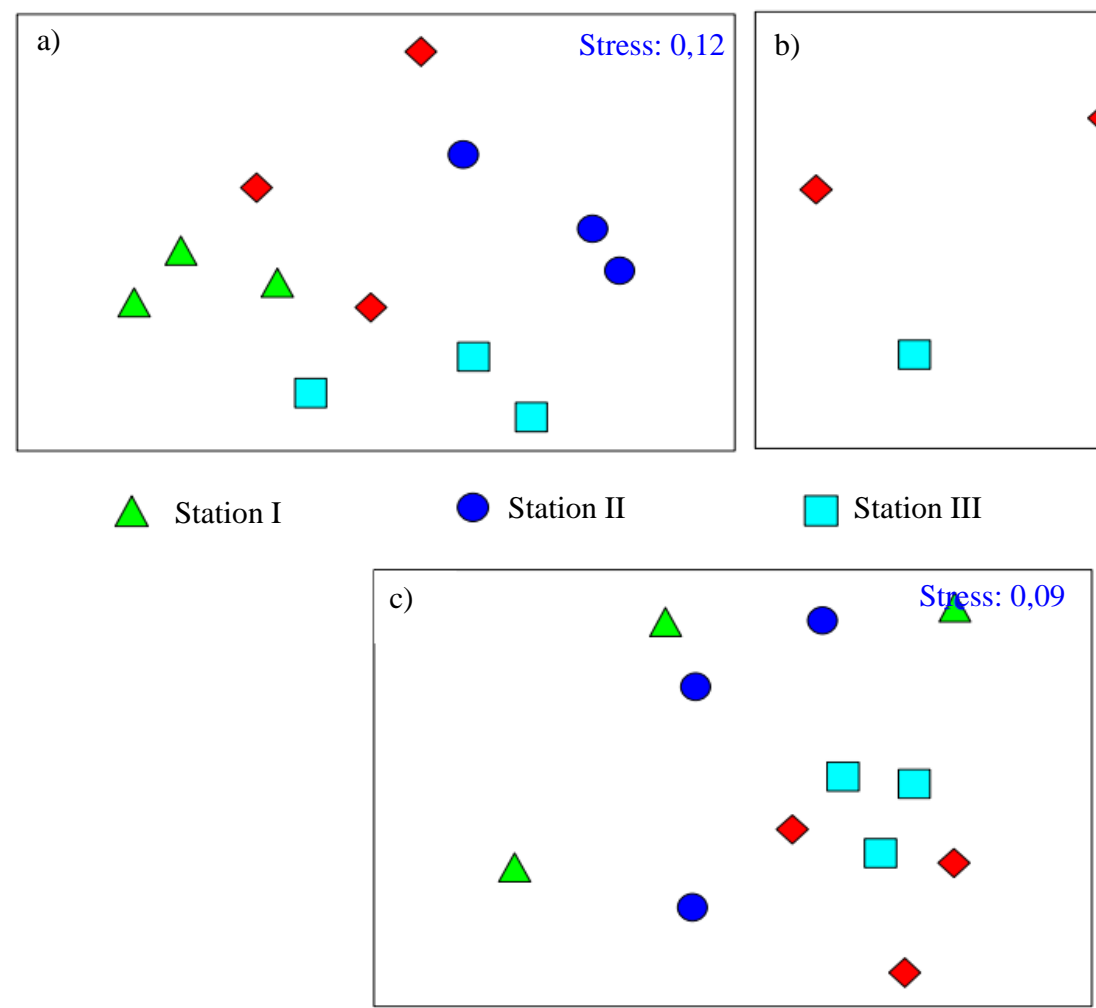

Fig. 4: nMDS ordination of $\log (x+1)$ transformation comparing the dinoflagellate cysts assemblages in term of total number of cyst/g DW sediment between location for each station: (a) Jeneberang Estuary, (b) Maros Estuary and (c) Pangkep Estuary 
Table 1: List of dinoflagellate cyst species with biological and paleontological name that found in surface sediment of three estuaries of Makassar Strait. Dinoflagellate cyst taxonomic name that used in this study are taken from (Alkawri, 2016; Aydin et al., 2011; Bravo et al., 2006; Godhe et al., 2000; Joyce et al., 2005; Kim et al., 2012; Mohamed and Al-Shehri, 2011; Narale and Anil, 2017; Nehring, 1997; Orlova et al., 2004; Pospelova et al., 2004; Shin et al., 2011; Uddandam et al., 2017)

\begin{tabular}{|c|c|c|}
\hline Dinoflagellate biological name & HABs species & Dinoflagellate cyst (Paleaontological name) \\
\hline Archaeperidinium sp. & Non-toxic & Cyst of Achaeperidinium sp. \\
\hline Alexandrium catenella & Yes & Cyst of Alexandrium catenella \\
\hline Alexandrium cf. minutum & Yes & Cyst of Alexandrium cf.minutum \\
\hline Alexadrium cf. tamarense & Yes & Cyst of Alexandrium cf.tamarense \\
\hline Alexandrium cf. tamiyavanachi & Non-toxic & Cyst of Alexandrium cf.tamayavanachi \\
\hline Alexandrium pseudogonyualax & Non-toxic & Cyst of Alexandrium pseudogonyualax \\
\hline Bicarinellum bicarinelloides & Non-toxic & Cyst of Bicarinellum bicarinelloides \\
\hline Brigatedinium asymmetricum & Non-toxic & Cyst of Brigatedinium asymmetricum \\
\hline Cochlodinium polykrikoides & Yes & Cyst of Cochlodinium polykrikoides \\
\hline Diatom & Non-toxic & - \\
\hline Diplopella symmetrica & Non-toxic & Dubridinium spp \\
\hline Dubridinium spp Potter & Non-toxic & Dubridinium spp \\
\hline Dubridinium spp & Non-toxic & Dubridinium spp \\
\hline Echidinium granulatum & Non-toxic & Unknown \\
\hline Foraminifera organic living & Non-toxic & - \\
\hline Fragilidium subglobosum & Non-toxic & Unknown \\
\hline Gonyaulax scrippsae & Non-toxic & Spiniferites bulloideus \\
\hline Gonyaulax verior & Non-toxic & Cyst of Gonyaulac verior \\
\hline Gymnodinium catenatum & Yes & Cyst of Gymnodinium catenatum \\
\hline Gymnodinium cf. nolleri & Non-toxic & Cyst of Gymnodinium cf.nolleri \\
\hline Gymnodinium instriatum & Non-toxic & Cyst of Gymnodinium instriatum \\
\hline Lejeunecysta oliva & Non-toxic & Unknown \\
\hline Operculodinium centrocarpum & Non-toxic & Protoceratium reticulatum \\
\hline Pentapharsodinium tyrrhenicum & Non-toxic & Unknown \\
\hline Pheopholykrikos hartmanii & Non-toxic & Cyst of P. hartmannii \\
\hline Polykrikos kotoidii & Non-toxic & Cyst of Polykrikos kotoidii \\
\hline Polykrikos schwartzii & Non-toxic & Cyst of Polykrikos schwartzii \\
\hline Protoceratium reticulum & Non-toxic & Perculodinium centrocarpum \\
\hline Protoperidinium avellana & Non-toxic & Brigantedinium cariacoense \\
\hline Protoperidinium conicoides & Non-toxic & Brigantedinium simplex \\
\hline Protoperidinium cf. americanum & Non-toxic & Cyst of Protoperidinium americanum \\
\hline Protoperidinium cf. divergen & Non-toxic & Echidinium aculeatum \\
\hline Protoperidinium claudicans & Non-toxic & Votadinium spinosum \\
\hline Protoperidinium cf. excentricum & Non-toxic & Echidinium delicatum \\
\hline Protoperidinium fukuyoi & Non-toxic & Echidinium granulatum \\
\hline Protoperidinium oblongum & Non-toxic & Votadinium calvum \\
\hline Protoperidinium pentagonum & Non-toxic & Triovantedinium applantum \\
\hline Protoperidinium punctulatum & Non-toxic & Echidinium $s p$ \\
\hline Protoperidinium subinerum & Non-toxic & Selenopemphrix nephroides \\
\hline Pyrophacus horologium & Non-toxic & Unknown \\
\hline Pyrophacus steinii & Non-toxic & Tuberculodinium vancampoae \\
\hline Scrippsiella cf. lachrymosa & Non-toxic & Cyst of Scrippsiella cf.lachrymosa \\
\hline Scrippsiella cf. rotunda & Non-toxic & Cyst of Scrippsiella cf.rotunda \\
\hline Scrippsiella crystallina & Non-toxic & Cyst of Scrippsiella crystallina \\
\hline Scrippsiella trifida & Non-toxic & Cyst of Scrippsiella trifida \\
\hline Scrippsiella trochoides & Yes & Cyst of Scrippsiella trochoides \\
\hline Selenopemprix nephroides & Non-toxic & Unknown \\
\hline Spiniferites elongatus & Non-toxic & Unknown \\
\hline Sxrystallin & Non-toxic & Unknown \\
\hline Votadiniium spinosum & Non-toxic & Protoperidinium claudican \\
\hline Zygabikodinium lenticulatum & Non-toxic & Unknown \\
\hline
\end{tabular}


Nita Rukminasari and Akbar Tahir / OnLine Journal of Biological Sciences 2021, 21 (2): 232.244 DOI: 10.3844/ojbsci.2021.232.244

Table 2: Location of sampling station along with water and sedimentary parameters

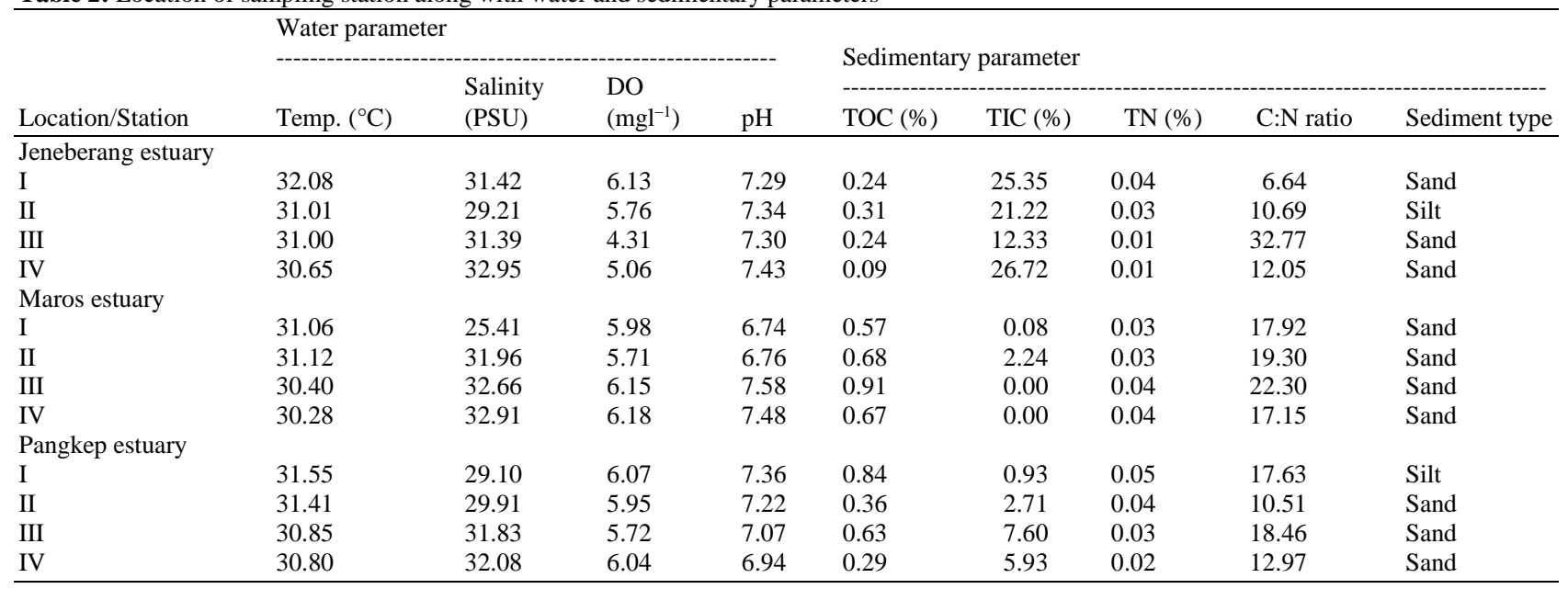

\section{Discussion}

Several biological parameters could be used as an effective indicator for environmental changing, namely: Phytoplankton composition, mainly diatoms and dinoflagellates cysts in particular (Rodrigues et al., 2019). Several diversity index, namely species composition, species diversity (Pospelova et al., 2002) and species-richness are also used to assess water quality including pollution and eutrophication (Rodrigues et al., 2019). Pospelova et al. (2004; 2002) used dinoflagellate cysts-based Fisher's $\alpha$ and species-richness (number of species) as indicators of environmental conditions in estuarine systems.

This study provided the first data about the abundance, composition and distribution of dinoflagellate cysts, including toxic species, in three estuaries of Makassar Strait. Species composition of dinoflagellate cysts from the sediment of three estuaries of Makassar Strait could be compared to in marine sediment of several previous study at Japan, Korea, Russia, India, Philippine, Aegean Sea, Sweden, Canada, Argentina, Saudi Arabia and China (Aydin et al., 2011; Baula et al., 2011; Candel et al., 2012; Godhe et al., 2000; Kim et al., 2012; Matsuoka and Fukuyo, 2000; Mertens et al., 2012; Mohamed and AlShehri, 2011; Pospelova et al., 2004; Shin et al., 2010; 2011) due to no early records of recent dinoflagellate cysts from Northern Makassar Strait. The comparison of dinoflagellate cyst assemblages in our study with nearby waters was not possible. The estuaries have different physical and environmental characteristics, therefore the response of dinoflagellate cysts to eutrophication in coastal waters may also depend on the type of estuary that is being investigated (Pospelova et al., 2002). A recent study by (Price et al., 2016) has shown that dinoflagellate cyst assemblages in estuaries vary by biogeographic province and that within a biogeographic province samples from the same estuary type generally had more similar assemblages compared to a different estuary type. In our study, the dinoflagellate cyst assemblages comprised mainly from cosmopolitan genera, such as Alexandrium, Cochlodinium, Gymnodinium, Pentapharsoodinium, Protoperidinium, Gonyaulax and Scrippsiella (Matsuoka and Fukuyo, 2000).

In general, tropical waters are characterized by low abundance and diverse dinoflagellate populations (Rodrigues et al., 2019). In our study sites, we found that there was a low diversity and species-richness. Furthermore, the diversity and species-richness values for dinoflagellate cysts in our study were lower than the values for temperate and tropical regions. Pospelova et al. (2004; 2002) suggested a decreasing in diversity and species-richness of dinoflagellate cyst taxa as a general indicator for toxic pollution and eutrophication estuarine system.

Our results showed that cyst species richness $(0.31$ $2.94)$ and diversity (0.30-1.16) were significantly lower in this study than in others. Baula et al. (2011) found that cyst species diversity at Balinao, Pangasinan was low with range of diversity index from 1.9 to 2.7 . A low dinoflagellate cyst species richness and diversity in our study indicated that the study sites were estuaries which a high nutrient loading. Pospelova et al. (2002) have been suggested that decreasing species diversity as an indicators of estuarine system which has a high nutrient loading. The Perinidiaceae (32\%) and Protoperidiniaceae $(28 \%)$ are abundant in all stations and locations. Gymnodiniaceae and Gonyaulacaceae species average $14 \%$ while Goniodoniaceae $(8 \%)$ and unidentified $(4 \%)$ were the represented group for a lesser contribution (Fig. 3). A high abundant of heterotrophic Protoperidiniaceae indicated that the waters in the study area was eutrophic. Previous study by (Hamel et al., 2002; Marret, 2003; Matsuoka, 1999; Matsuoka et al., 2003; Radi and de Vernal, 2004) found that Protoperidiniace was a good indicator for eutrophic waters. Kim et al. (2009) stated that Protoperidiniaceae as a heterotrophic dinoflagellate can be more abundant than autotrophic dinoflagellate in eutrophic coastal environment. 
We found that sediment characteristics influenced cyst abundance, where sandy sediments tended to have a lower cyst concentration. The sediment characteristics in our study sites was mostly sandy sediment, consequently cysts abundance was low and ranged from 35 cysts $\mathrm{g}^{-1} \mathrm{DW}$ sediment to 1135 cysts $\mathrm{g}^{-1} \mathrm{DW}$ sediment. This finding in lined with previous study, which reported dinoflagellate cysts was higher abundance in muddy sediments than those of in sandy sediments (Anderson et al., 2005; Nehring, 1993b; Olli and Trunov, 2010). This may be due to behavior of dinoflagellate cyst to deposit their cyst in fine particles and that their abundance increases in sediments with a higher mud contents (De Vernal et al., 2013). Dinoflagellate cyst distributions in the sediments was influenced by the cyst production patterns in the overlying water column and specific encystment strategies of dinoflagellate species (Anderson et al., 2005; Dale, 1976; Kremp et al., 2009).

Our finding demonstrated trends and groupings of dinoflagellate cysts based on species composition and abundance. The pattern of species assemblages and abundant indicated a functions of water depth, sediment grain size and nutrients (TOC, TIC, TN and N:P Ratios). We found that there is a trend that sites with a lower TOC values have a higher values of species richness. This finding contradicts with previous study by (Pospelova and Kim, 2010) who found that there is a trend that sites with the higher TOC values have lower values of species richness. Marret (2003) have identified the most important environmental variables that can be related to the distribution patterns dinoflagellate cysts in the world, namely Sea Surface Temperature (SST), phosphate and nitrate concentrations. Marret et al. (2004) found that cysts are distributed according to stratification and grain size classes sediment. In Sunda Shelf, South China Sea, cyst distribution is related to water depth, total organic carbon and sediment grain size (Kawamura, 2004). In this study, Table 1 summarized the water and sediment parameters to dinoflagellate cyst species composition.

We also found dinoflagellate cysts species that potentially harmful in three estuaries of Makassar Strait sediments. The cysts belonged to the toxin-producing species of Alexandrium catenella, A. minutum, Cochlodinium polykrikoides, Gymnodinium catenatum and Scrippsiella trochoidea were found at several stations of sampling sites. The presence of harmful marine dinoflagellate cysts in marine sediments has been documented worldwide (Anderson et al., 2005; Fahnenstiel et al., 2009; Matsuoka et al., 2003; Pitcher and Joyce, 2009). In addition, the dinoflagellate cysts can be very toxic (up to 10 times more toxic than vegetative cells), it could be source of poison to organisms (Zingone et al., 2020).

\section{Conclusion}

Species composition, diversity, species richness and cyst abundance among the study sites was not a significant difference in. Sediment characteristics was strongly affecting the abundance of dinoflagellate cysts: Cyst abundances were low at all sampling sites due to sampling sites was mostly sandy sediment. Our study also found that there were five potentially toxic cysts and harmful species that was detected in all sampling sites, so the study areas was potential for occurring HABs.

\section{Acknowledgement}

This research was funded by Directorate Research and Community Service, Ministry of Education and Culture, Republic of Indonesia, under research scheme of Basic Research with the contract number: 1516/UN4.22/PT.01.03/2020. Author would like to thanks to head of Water Quality and Aquatic Productivity Laboratory who facilitated us for sediment samples analysis. We thank to Director of Center of Excellent and Innovation of Seaweed Development and Utilization who has provided us with room and facilities for running experiment and analyzing our samples. Thanks to Head of Gowa, Maros and Pangkep Regency who have given a permission for conducting sampling in their areas. Thanks also for our students (Febrianti, Nurhudaya, Suci, Desi, Juwiti, Surahma, Anisa, Nur Rosyida and Rahmat) who helping us in sampling and processing our samples.

\section{Funding Information}

This study was funded by Directorate Research and Community Service, Ministry of Education and Culture, Republic of Indonesia, with the contract number: 1516/UN4.22/PT.01.03/2020.

\section{Author's Contributions}

Nita Rukminasari: Designed a sampling method, conducted field sampling, data analysis and interpretation, writing a draft manuscript, submitting a manuscript.

Akbar Tahir: Designed a sampling method, data interpretation, final editing and proofreading of manuscript before submitting.

\section{Ethics}

This article does not contain any studies with animals performed by any of the authors.

\section{References}

Alkawri, A. (2016). Seasonal variation in composition and abundance of harmful dinoflagellates in Yemeni waters, southern Red Sea. Marine Pollution Bulletin, 112(1-2),

225-234 https://doi.org/10.1016/j.marpolbul.2016.08.015 
Anderson, D. M., \& Wall, D. (1978). Potential importance of benthic cysts of Gonyaulax tamarensis and $\mathrm{G}$. excavata in initiating toxic dinoflagellate blooms 1 , 2, 3. Journal of Phycology, 14(2), 224-234. https://doi.org/10.1111/j.1529-8817.1978.tb02452.x

Anderson, D. M., Stock, C. A., Keafer, B. A., Nelson, A. B., Thompson, B., McGillicuddy Jr, D. J., ... \& Martin, J. (2005). Alexandrium fundyense cyst dynamics in the Gulf of Maine. Deep Sea Research Part II: Topical Studies in Oceanography, 52(19-21), 2522-2542. https://doi.org/10.1016/j.dsr2.2005.06.014

Anglès, S., Jordi, A., Garcés, E., Basterretxea, G., \& Palanques, A. (2010). Alexandrium minutum resting cyst distribution dynamics in a confined site. Deep Sea Research Part II: Topical Studies in Oceanography, 57(3-4), 210-221. https://doi.org/10.1016/j.dsr2.2009.09.002

Aydın, H., Matsuoka, K., \& Minareci, E. (2011). Distribution of dinoflagellate cysts in recent sediments from Izmir Bay (Aegean Sea, Eastern Mediterranean). Marine Micropaleontology, 80(1-2), 44-52. https://doi.org/10.1016/j.marmicro.2011.03.004

Baula, I. U., Azanza, R. V., Fukuyo, Y., \& Siringan, F. P. (2011). Dinoflagellate cyst composition, abundance and horizontal distribution in Bolinao, Pangasinan, Northern Philippines. Harmful Algae, 11, 33-44. https://doi.org/10.1016/j.hal.2011.07.002

Bravo, I., Garcés, E., Diogène, J., Fraga, S., Sampedro, N., \& Figueroa, R. I. (2006). Resting cysts of the toxigenic dinoflagellate genus Alexandrium in recent sediments from the Western Mediterranean coast, including the first description of cysts of A. kutnerae and A. peruvianum. European Journal of Phycology, 41(3), 293-302. https://doi.org/10.1080/09670260600810360

Bremner, J. M. (1996). Total Nitrogen, in: Methods of Soil Analysis. Soil Science Society of America, Inc, Wisconsin, USA, pp. 1085-1121. https://doi.org/10.2134/agronmonogr9.2.c32

Candel, M. S., Radi, T., de Vernal, A., \& Bujalesky, G. (2012). Distribution of dinoflagellate cysts and other aquatic palynomorphs in surface sediments from the Beagle Channel, Southern Argentina. Marine Micropaleontology, 96, 1-12. https://doi.org/10.1016/j.marmicro.2012.06.009

D’Silva, M. S., Anil, A. C., \& Sawant, S. S. (2013). Dinoflagellate cyst assemblages in recent sediments of Visakhapatnam harbour, east coast of India: Influence of environmental characteristics. Marine Pollution Bulletin, 66(1-2), 59-72. https://doi.org/10.1016/j.marpolbul.2012.11.012
Dale, B. (1976). Cyst formation, sedimentation and preservation: factors affecting dinoflagellate assemblages in recent sediments from Trondheimsfjord, Norway. Review of Palaeobotany and Palynology, 22(1), 39-60. https://doi.org/10.1016/0034-6667(76)90010-5

De Vernal, A., Rochon, A., \& Radi, T. (2013). Paleoceanography, Biological Proxies| Dinoflagellates. https://doi.org/10.1016/B978-0-44453643-3.00283-1

Elbrächter, M. (2003). Dinophyte reproduction: progress and conflicts. Journal of Phycology, 39(4), 629-632. https://doi.org/10.1046/j.15298817.2003.39041.x

Eynaud, F., Turon, J. L., \& Duprat, J. (2004). Comparison of the Holocene and Eemian palaeoenvironments in the South Icelandic Basin: dinoflagellate cysts as proxies for the North Atlantic surface circulation. Review of Palaeobotany and Palynology, 128(1-2), 55-79. https://doi.org/10.1016/S0034-6667(03)00112-X

Fahnenstiel, G., Hong, Y., Millie, D., Doblin, M., Johengen, T., \& Reid, D. (2009). Marine dinoflagellate cysts in the ballast tank sediments of ships entering the Laurentian Great Lakes. Internationale Vereinigung für theoretische und angewandte Limnologie: Verhandlungen, $\quad 30(7), \quad$ 1035-1038. https://doi.org/10.1080/03680770.2009.11902295

Figueroa, R. I., Garces, E., \& Bravo, I. (2007). Comparative study of the life cycles of Alexandrium tamutum and Alexandrium minutum (Gonyaulacales, Dinophyceae) in culture 1. Journal of Phycology, 43(5), 1039-1053. https://doi.org/10.1111/j.15298817.2007.00393.x

Godhe, A., Karunasagar, I., \& Karlson, B. (2000). Dinoflagellate cysts in recent marine sediments from SW India. Botanica Marina, 43(1), 39-48. https://doi.org/10.1515/BOT.2000.004

Glibert, P.M., \& Pitcher, G., (2001). GEOHAB: Global ecology and oceanography of harmful algal blooms.

Hallegraeff, G. M., Anderson, D. M., Cembella, A. D., \& Enevoldsen, H. O. (2004). Manual on harmful marine Microalgae. Unesco.

Hamel, D., de Vernal, A., Gosselin, M., \& HillaireMarcel, C. (2002). Organic-walled microfossils and geochemical tracers: sedimentary indicators of productivity changes in the North Water and northern Baffin Bay during the last centuries. Deep Sea Research Part II: Topical Studies in Oceanography, 49(22-23), 5277-5295 https://doi.org/10.1016/S0967-0645(02)00190-X 
Harland, R., Nordberg, K., \& Filipsson, H. L. (2004). A highresolution dinoflagellate cyst record from latest Holocene sediments in Koljö Fjord, Sweden. Review of Palaeobotany and Palynology, 128(1-2), 119-141. https://doi.org/10.1016/S0034-6667(03)00116-7

Holzwarth, U., Esper, O., \& Zonneveld, K. (2007). Distribution of organic-walled dinoflagellate cysts in shelf surface sediments of the Benguela upwelling system in relationship to environmental conditions. Marine Micropaleontology, 64(1-2), 91-119. https://doi.org/10.1016/j.marmicro.2007.04.001

Horner, R. A., Greengrove, C. L., Davies-Vollum, K. S., Gawel, J. E., Postel, J. R., \& Cox, A. M. (2011). Spatial distribution of benthic cysts of Alexandrium catenella in surface sediments of Puget Sound, Washington, USA. Harmful Algae, 11, 96-105. https://doi.org/10.1016/j.hal.2011.08.004

Joyce, L. B., Pitcher, G. C., Du Randt, A., \& Monteiro, P. M. S. (2005). Dinoflagellate cysts from surface sediments of Saldanha Bay, South Africa: an indication of the potential risk of harmful algal blooms. Harmful Algae, 4(2), 309-318. https://doi.org/10.1016/j.hal.2004.08.001

Kawamura, H. (2004). Dinoflagellate cyst distribution along a shelf to slope transect of an oligotrophic tropical sea (Sunda Shelf, South China Sea). Phycological Research, 52(4), 355-375. https://doi.org/10.1111/j.1440-1835.2004.tb00345.x

Kim, S. Y., Lim, D. I., \& Cho, H. J. (2012). Dinoflagellate cyst assemblages from the northern shelf sediments of the East China Sea: An indicator of marine productivity. Marine Micropaleontology, 96, 75-83. https://doi.org/10.1016/j.marmicro.2012.09.003

Kim, S. Y., Moon, C. H., Cho, H. J., \& Lim, D. I. (2009). Dinoflagellate cysts in coastal sediments as indicators of eutrophication: a case of Gwangyang Bay, South Sea of Korea. Estuaries and Coasts, 32(6), 1225-1233. https://doi.org/10.1007/s12237009-9212-6

Kremp, A., Rengefors, K., \& Montresorc, M. (2009). Species specific encystment patterns in three Baltic cold-water dinoflagellates: The role of multiple cues in resting cyst formation. Limnology and Oceanography, 54(4), 1125-1138 https://doi.org/10.4319/lo.2009.54.4.1125

Lewis, J., Harris, A. S. D., Jones, K. J., \& Edmonds, R. L. (1999). Long-term survival of marine planktonic diatoms and dinoflagellates in stored sediment samples. Journal of Plankton Research, 21(2). https://doi.org/10.1093/plankt/21.2.343
Marret, F. (2003). Figures of dinoflagellate cysts (relative abundance, temperature, salinity and nutrients). Supplement to: Marret, F; Zonneveld, KAF (2003): Atlas of modern organic-walled dinoflagellate cyst distribution. Rev. Palaeobot. Palynol., 125(1-2), 1-200. https://doi.org/10.1016/S0034-6667(02)00229-4

Matsuoka, K. (1999). Eutrophication process recorded in dinoflagellate cyst assemblages-a case of Yokohama Port, Tokyo Bay, Japan. Science of the Total Environment, 231(1), 17-35. https://doi.org/10.1016/S0048-9697(99)00087-X

Matsuoka, K., \& Fukuyo, Y. A. S. U. W. O. (2000). Technical guide for modern dinoflagellate cyst study. WESTPAC-HAB, Japan Society for the Promotion of Science, Tokyo, Japan, 47.

Matsuoka, K., Joyce, L. B., Kotani, Y., \& Matsuyama, Y. (2003). Modern dinoflagellate cysts in hypertrophic coastal waters of Tokyo Bay, Japan. Journal of Plankton Research, 25(12), 1461-1470. https://doi.org/10.1093/plankt/fbg111

Meng, J., Yao, P., Yu, Z., Bianchi, T. S., Zhao, B., Pan, H., \& Li, D. (2014). Speciation, bioavailability and preservation of phosphorus in surface sediments of the Changjiang Estuary and adjacent East China Sea inner shelf. Estuarine, Coastal and Shelf Science, 144, 27-38. https://doi.org/10.1016/j.ecss.2014.04.015

Mertens, K. N., Price, A. M., \& Pospelova, V. (2012). Determining the absolute abundance of dinoflagellate cysts in recent marine sediments II: further tests of the Lycopodium marker-grain method. Review of Palaeobotany and Palynology, 184, 74-81. https://doi.org/10.1016/j.revpalbo.2012.06.012

Mohamed, Z. A., \& Al-Shehri, A. M. (2011). Occurrence and germination of dinoflagellate cysts in surface sediments from the Red Sea off the coasts of Saudi Arabia. Oceanologia, 53(1), 121-136. https://doi.org/10.5697/oc.53-1.121

Marret, F., Eiríksson, J., Knudsen, K.L., Turon, J.L., Scourse, J.D., 2004. Distribution of dinoflagellate cyst assemblages in surface sediments from the northern and western shelf of Iceland. Rev. Palaeobot. Palynol. 128, 35-53. https://doi.org/10.1016/S0034-6667(03)00111-8

Narale, D. D., \& Anil, A. C. (2017). Spatial distribution of dinoflagellates from the tropical coastal waters of the South Andaman, India: implications for coastal pollution monitoring. Marine pollution bulletin, 115(1-2), 498-506. https://doi.org/10.1016/j.marpolbul.2016.11.035 
Nehring, S. (1993a). Mortality of dogs associated with a mass development of Nodularia spumigena (Cyanophyceae) in a brackish lake at the German North Sea coast. Journal of Plankton Research, 15(7), 867-872. https://doi.org/10.1093/plankt/15.7.867

Nehring, S. (1993b). Mechanisms for recurrent nuisance algal blooms in coastal zones: resting cyst formation as life-strategy of Dinoflagellates. Lang.

Nehring, S. (1997). Dinoflagellate resting cysts from recent German coastal sediments. Botanica Marina, 40(1-6), $307-324$ https://doi.org/10.1515/botm.1997.40.1-6.307

Olli, K., \& Trunov, K. (2010). Abundance and distribution of vernal bloom dinoflagellate cysts in the Gulf of Finland and Gulf of Riga (the Baltic Sea). Deep Sea Research Part II: Topical Studies in Oceanography, 57(3-4), 235-242. https://doi.org/10.1016/j.dsr2.2009.09.009

Orlova, T. Y., Morozova, T. V., Gribble, K., Kulis, D., \& Anderson, D. M., (2004). Dinoflagellate cysts in recent marine sediments of the western coast of the Bering Sea. Bot. Mar. 47, 184-201. https://doi.org/10.1515/BOT.2004.019

Pitcher, G. C., \& Joyce, L. B. (2009). Dinoflagellate cyst production on the southern Namaqua shelf of the Benguela upwelling system. Journal of Plankton Research, 31(8), 865-875. https://doi.org/10.1093/plankt/fbp040

Pospelova, V., \& Kim, S. J. (2010). Dinoflagellate cysts in recent estuarine sediments from aquaculture sites of southern South Korea. Marine Micropaleontology, 76(1-2), $37-51$. https://doi.org/10.1016/j.marmicro.2010.04.003

Pospelova, V., Chmura, G. L., \& Walker, H. A. (2004). Environmental factors influencing the spatial distribution of dinoflagellate cyst assemblages in shallow lagoons of southern New England (USA). Review of Palaeobotany and Palynology, 128(1-2), 7-34. 6667(03)00110-6

Pospelova, V., Chmura, G. L., Boothman, W. S., \& Latimer, J. S. (2002). Dinoflagellate cyst records and human disturbance in two neighboring estuaries, New Bedford Harbor and Apponagansett Bay, Massachusetts (USA). Science of the Total Environment, 298(1-3), 81-102. https://doi.org/10.1016/S0048-9697(02)00195-X

Price, A. M., Gurdebeke, P. R., Mertens, K. N., \&, V. (2016). Determining the absolute abundance of dinoflagellate cysts in recent marine sediments III: Identifying the source of Lycopodium loss during palynological processing and further testing of the Lycopodium marker-grain method. Review of Palaeobotany and Palynology, 226, 78-90. https://doi.org/10.1016/j.revpalbo.2015.12.009
Radi, T., \& de Vernal, A. (2004). Dinocyst distribution in surface sediments from the northeastern Pacific margin $(40-60 \mathrm{~N})$ in relation to hydrographic conditions, productivity and upwelling. Review of Palaeobotany and Palynology, 128(1-2), 169-193. https://doi.org/10.1016/S0034-6667(03)00118-0

Rodrigues, R. V., Patil, J. S., Sathish, K., \& Anil, A. C. (2019). Dinoflagellate planktonic-motile-stage and benthic-cyst assemblages from a monsooninfluenced tropical harbour: Elucidating the role of environmental conditions. Estuarine, Coastal and Shelf Science, 226, 106253. https://doi.org/10.1016/j.ecss.2019.106253

Sherrod, L. A., Dunn, G., Peterson, G. A., \& Kolberg, R. L. (2002). Inorganic carbon analysis by modified pressure-calcimeter method. Soil Science Society of America Journal, 66(1), 299-305. https://doi.org/10.2136/sssaj2002.0299

Shin, H. H., Matsuoka, K., Yoon, Y. H., \& Kim, Y. O. (2010). Response of dinoflagellate cyst assemblages to salinity changes in Yeoja Bay, Korea. Marine Micropaleontology, 77(1-2), 15-24. https://doi.org/10.1016/j.marmicro.2010.07.001

Shin, H. H., Yoon, Y. H., Kim, Y. O., \& Matsuoka, K. (2011). Dinoflagellate cysts in surface sediments from southern coast of Korea. Estuaries and Coasts, 34(4), 712-725. https://doi.org/10.1007/s12237-0119373-y

Tiselius, P., \& Kuylenstierna, M. (1996). Growth and decline of a diatom spring bloom phytoplankton species composition, formation of marine snow and the role of heterotrophic dinoflagellates. Journal of Plankton Research, 18(2), 133-155. https://doi.org/10.1093/plankt/18.2.133

Triki, H. Z., Laabir, M., Lafabrie, C., Malouche, D., Bancon-Montigny, C., Gonzalez, C., ... \& DalyYahia, O. K. (2017). Do the levels of industrial pollutants influence the distribution and abundance of dinoflagellate cysts in the recently-deposited sediment of a Mediterranean coastal ecosystem?. Science of the Total Environment, 595, 380-392. https://doi.org/10.1016/j.scitotenv.2017.03.183

Uddandam, P. R., Prasad, V., \& Rai, J. (2017). Dinoflagellate cyst distribution in sediments of western Bay of Bengal: Role of sea surface conditions. Palaeogeography, Palaeoclimatology, Palaeoecology, 483, 31-48. https://doi.org/10.1016/j.palaeo.2017.01.013

Zingone, A., Escalera, L., Aligizaki, K., FernándezTejedor, M., Ismael, A., Montresor, M., ... \& Totti, C. (2020). Toxic marine microalgae and noxious blooms in the Mediterranean Sea: A contribution to the Global HAB Status Report. Harmful Algae, 101843. https://doi.org/10.1016/j.hal.2020.101843 
Supplement 1: Two-way ANOVA results to examine the spatial variation in dinoflagellate cyst abundance (N), Shannon-Wainer's diversity index (H'), Margalef's species richness (d), and Pielou's evenness (J') in three estuaries of Makassar Strait (Jeneberang Estuary, Maros Estuary and Pangkep Estuary).

\begin{tabular}{|c|c|c|c|c|c|}
\hline Factor & df & SS & MS & fs & P value \\
\hline \multicolumn{6}{|l|}{$\mathbf{N}$} \\
\hline Location & 2 & 37991 & 18995 & 0.1042 & 0.7815 \\
\hline Station & 3 & 205387 & 68462 & 1.0690 & 0.4225 \\
\hline Location x Station & 6 & 507530 & 84588 & 2.0880 & 0.2496 \\
\hline Cysts abundance $\mathrm{x}$ Location & 4 & 729476 & 182369 & & \\
\hline Cysts abundance $\mathrm{x}$ Station & 6 & 384420 & 64070 & & \\
\hline Cysts abundance & 2 & 68015 & 34007 & & \\
\hline Residual & 12 & 486224 & 40519 & & \\
\hline \multicolumn{6}{|l|}{ d } \\
\hline Location & 2 & 0.5071 & 0.2535 & 4.3010 & 0.1079 \\
\hline Station & 3 & 1.7320 & 0.5775 & 2.8810 & 0.2301 \\
\hline Location x Station & 6 & 4.0700 & 0.6784 & 1.6590 & 0.3200 \\
\hline Species richness $\mathrm{x}$ Location & 4 & 0.2358 & 0.0590 & & \\
\hline Species richness x Station & 6 & 1.2030 & 0.2004 & & \\
\hline Species richness & 2 & 0.5805 & 0.2903 & & \\
\hline Residual & 12 & 4.9080 & 0.4090 & & \\
\hline \multicolumn{6}{|l|}{$\mathbf{J}^{\prime}$} \\
\hline Location & 2 & 0.0224 & 0.0112 & 1.1860 & 0.3904 \\
\hline Station & 3 & 0.0186 & 0.0062 & 0.5266 & 0.5449 \\
\hline Location $x$ Station & 6 & 0.1016 & 0.0169 & 2.2460 & 0.2334 \\
\hline Evenness index $x$ Location & 4 & 0.0378 & 0.0094 & & \\
\hline Evenness index x Station & 6 & 0.0705 & 0.0118 & & \\
\hline Evenness index & 2 & 0.0003 & 0.0002 & & \\
\hline Residual & 12 & 0.0905 & 0.0075 & & \\
\hline \multicolumn{6}{|l|}{$\mathbf{H}^{\prime}$} \\
\hline Location & 2 & 0.0087 & 0.0044 & 0.5453 & 0.5768 \\
\hline Station & 3 & 0.1705 & 0.0568 & 2.2310 & 0.2726 \\
\hline Location $\mathrm{x}$ Station & 6 & 0.2438 & 0.0406 & 1.0140 & 0.4222 \\
\hline Shannon-Wainer index x Location & 4 & 0.0321 & 0.0080 & & \\
\hline Shannon-Wainer index x Station & 6 & 0.1529 & 0.0255 & & \\
\hline Shannon-Wainer index & 2 & 0.0069 & 0.0035 & & \\
\hline Residual & 12 & 0.4807 & 0.0401 & & \\
\hline
\end{tabular}

Supplement 2: Results from an ANOSIM Pairwise test and SIMPER comparing dinoflagellate cyst assemblages between station for each location. Table displays Global R, Significance level (\%), Dissimilarity $(\%)$ and the taxa most responsible for dissimilarity

\begin{tabular}{|c|c|c|c|c|}
\hline \multirow[b]{2}{*}{ Pair } & \multicolumn{3}{|c|}{ ANOSIM Pairwise Tests } & \multirow{2}{*}{$\begin{array}{l}\text { SIMPER Results } \\
\text { Taxa most responsible for dissimilarity }\end{array}$} \\
\hline & $\begin{array}{l}\text { Global } \\
\mathrm{R}\end{array}$ & $\begin{array}{l}\text { Significance } \\
\text { level (\%) }\end{array}$ & $\begin{array}{l}\text { Dissimilarity } \\
(\%)\end{array}$ & \\
\hline Jeneberang Estuary & 0.569 & 0.002 & & \\
\hline Station I vs Station II & 0.963 & 10 & 78.85 & Scrippsiella trifida (11\%), Pyrophacus horologium (11\%), Pentapharsodinium tyrrhenicum (9\%) \\
\hline Station I vs Station III & 0.815 & 10 & 68.28 & Scrippsiella trifida (17\%), Pyrophacus horologium (14\%), Foraminifera org living (11\%) \\
\hline Station I vs Station IV & 0.185 & 20 & 55.69 & Scrippsiella trifida (16\%), Pyrophacus horologium (15\%), Alexandrium catenella (12\%) \\
\hline Station II vs Station III & 0.556 & 10 & 64.08 & Foraminifera org living (10\%), Protoperidinium subinerum (9\%), Scrippsiella trochoides (9\%) \\
\hline Station II vs Station IV & 0.481 & 20 & 67.07 & Pyrophacus horologium (10\%), Scrippsiella crystallina (9\%), Scrippsiella trifida (9\%) \\
\hline Maros Estuary & 0.105 & 0.21 & & \\
\hline Station I vs Station II & -0.259 & 100 & 41.62 & Scrippsiella trifida (13\%), Alexandrium catenella (10\%), Scrippsiella crystallina (9\%) \\
\hline Station I vs Station III & 0.296 & 30 & 66.85 & Scrippsiella crystallina (11\%), Alexandrium catenella (10\%), Scrippsiella trifida (9\%) \\
\hline Station I vs Station IV & 0.296 & 10 & 69.34 & Scrippsiella crystallina (9\%), Protoperidinium subinerum (9\%), Cochlodinium polykrikoides (8\%) \\
\hline Station II vs Station III & -0.037 & 50 & 64.33 & Pentapharsodinium tyrrhenicum (10\%), Scrippsiella trifida (9\%), Scrippsiella crystallina ( $8 \%$ ) \\
\hline Station II vs Station IV & 0.296 & 20 & 74.27 & Scrippsiella trifida (9\%), Pentapharsodinium tyrrhenicum (8\%), Protoperidinium subinerum (8\%) \\
\hline Station III vs Station IV & -0.037 & 50 & 76.99 & Alexandrium catenella (10\%), Protoperidinium subinerum (8\%), Scrippsiella trifida (7\%) \\
\hline Pangkep Estuary & 0.253 & 0.042 & & \\
\hline Station I vs Station II & -0.259 & 80 & 63.82 & Pentapharsodinium tyrrhenicum (8\%), Gymnodinium catenatum (7\%), Foraminifera org living (7\%) \\
\hline Station I vs Station III & 0.148 & 20 & 71.56 & Zygabikodinium lenticulatum (7\%), Pentapharsodinium tyrrhenicum (7\%), Scrippsiella cf.lachrymosa (7\%) \\
\hline Station II vs Station III & 0.556 & 10 & 60.64 & Scrippsiella trochoides $(11 \%)$, Zygabikodinium lenticulatum (10\%), Gymnodinium catenatum (7\%) \\
\hline Station II vs Station IV & 0.556 & 10 & 67.58 & Scrippsiella trochoides (9\%), Scrippsiella cf.lachrymosa (8\%), Zygabikodinium lenticulatum (7\%) \\
\hline Station III vs Station IV & 0.148 & 20 & 45.57 & Gonyaulax verior (15\%), Foraminifera org living (11\%), Scrippsiella crystallina (9\%) \\
\hline
\end{tabular}

